\title{
A Passage from India
}

\author{
David Berlinski
}

\author{
Bland Fanatics: Liberals, Race and Empire \\ by Pankaj Mishra \\ Farrar, Strauss \& Giroux, 224 pp., \$27.00.
}

$\mathrm{P}$ ANKAJ MISHRA is an Indian journalist, novelist, and travel writer; he is widely appreciated as a scold. ${ }^{1}$ Written between 2008 and just the other day, the sixteen essays comprising Bland Fanatics were published variously in the Guardian, the London Review, the New Yorker, the New York Times, and the New York Review. ${ }^{2}$ Readers seeking ideological exuberance must look elsewhere. The essays are themselves unified by a common rhetorical strategy, if not a common rhetorical subject, in which Mishra reveals that he knows something that others do not. "It had long been clear to me," he writes, "that Western ideologues during the Cold War absurdly prettified the rise of the 'democratic' West."”

What I didn't realise until I started to inhabit the knowledge ecosystems of London and New York is how evasions and suppressions had resulted, over time, in a massive store of defective knowledge about the West and the non-West alike. Simple-minded and misleading ideas and assumptions, drawn from this blinkered history, had come to shape the speeches of Western statesmen, think tank reports and newspaper editorials, while supplying fuel to countless log-rolling columnists, television pundits and terrorism experts. ${ }^{4}$

Living on hot air, logrolling columnists, like certain abstemious yogis, do not generally require fuel, although they may require logs; and a knowledge ecosystem suggests nothing so much as a child's terrarium: wood, water, weeds, worms. Never mind. Readers will get the point. They could hardly miss it. In hanging around London and New York, Mishra encountered a good many dopes.

No doubt.

Mishra was moved to republish these essays in their hardcover coffin, he remarks in his introduction, as a response to Brexit, the election of Donald Trump, and the COVID-19 pandemic. The majority of these essays were written before Brexit, the election of Trump, or the advent of COVID-19. They lack the degree of prophetic force that Mishra might think appropriate. The title itself reprises a phrase due to Reinhold Niebuhr: "[A]mong the lesser culprits of history," Niebuhr wrote in 1959, "are the bland fanatics of western civilization who regard the highly contingent achievements of our culture as the final form and norm of human existence." ${ }^{5}$ Mishra's bland fanatics, treating things alphabetically, run from Martin Amis, Ayaan Hirsi Ali, and Francis Fukuyama to Steven Pinker, Bari Weiss, and Leon Wieseltier, all of them bland, none of them fanatical. Robert Blackwill, Dick Cheney, Richard Perle, Condoleezza Rice, Paul Wolfowitz, and Robert Zoellick are unaccountably beyond the beam of Mishra's indignation. I would have thought that Cheney, at least, had the beady eyes characteristic of the born bland fanatic.

Two of the sixteen essays in this collection are devoted to single combat: Mishra vs. Niall Ferguson and Jordan Peterson. Fluffy and forgettable, they did succeed in provoking their subjects to a display of petulance. Ferguson threatened to sue Mishra for libel, and Peterson proposed to slap him silly should they happen to meet.

What a pity they did not.

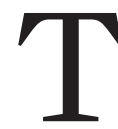

HE ESSAYS IN Bland Fanatics, if intelligent and brisk, are also imperfectly argued and badly written. Realities are brutal, falsehoods blatant, notions reek, prejudices are entrenched, binaries pop up here and there (eager, I am sure, to escape gender confinement), crime rates skyrocket, adventurers are bumptious, history is blinkered, delusions climax, despotisms are ruthless, and, if breasts are not being bared, chests, at least, are being thumped. ${ }^{6}$ Mishra is also a writer unwilling to savor the niceties of attribution. The wonderful phrase "closing time in the garden of the West" appears three times in two essays, welcome relief from the clump of Mishra's habitual clichés. It is due to Cyril Connolly.7 That "every document of civilization is also a document of barbarism" is due, in turn, to Walter Benjamin. ${ }^{8}$ Mishra has appropriated the phrase and its mistranslation into English.

The consistent defect in these essays is less their style and more the impression that Mishra conveys of chewing more than he has bitten off. In his thoughts on 
British imperialism, Mishra is, of course, very much a made member of the moral majority: if not a capo, then surely a consigliere. ${ }^{9}$ The knowledge ecosystem of London and New York having provoked his contempt, Mishra remains curiously unembarrassed in appealing to the camouflage of its consensus. Geschmack. British imperialism? Racist, illegitimate, predatory, despotic. In defending the British Empire, Niall Ferguson enjoys, in this regard, the lurid appeal of a man proposing to speak in favor of the rack at a gathering of Quakers. ${ }^{10}$ Mishra is appalled:

Astonishingly, British imperialism, seen for decades by Western scholars and anti-colonial leaders alike as a racist, illegitimate and often predatory despotism, came to be repackaged in our own time as a benediction that, in Ferguson's words, “undeniably pioneered free trade, free capital movements and, with the abolition of slavery, free labour."11

It is unclear whether Mishra thinks that Ferguson's benediction was not beneficial or that it was otherwise withheld. "Never mind," he says,

that free trade, introduced to Asia through gunboats, destroyed nascent industry in conquered countries, that "free" capital mostly went to the white settler states of Australia and Canada, and that indentured rather than "free" labor replaced slavery.

He does not stay to argue these points..$^{12}$ And for every good reason. Someone might argue back. ${ }^{13}$

And, in fact, Ferguson does: ${ }^{14}$

The British created an integrated Indian market: they unified weights, measures and the currency, abolished transit duties and introduced a "legal framework [which] promoted private property rights and contract law more explicitly." They invested substantially in repairing and enlarging the country's ancient irrigation system: between 1891 and 1938, the acreage under irrigation more than doubled. As is well known, the British transformed the Indian system of communications, introducing a postal and telegraph system, deploying steamships on internal waterways and building more than 40,000 miles of railway track (roughly five times the amount constructed in China in the same period). The railway network alone employed more than a million people by the last decade of British rule. Finally, there was a significant increase in financial intermediation. $^{15}$

And not only Ferguson. In The Economic History of India, 1857-1947, Tirthankar Roy writes that

[t]he railways, the ports, major irrigation systems, the telegraph, sanitation and medical care, the universities, the postal system, the courts of law, were assets India could not believably have acquired in such extent and quality had it not developed close political links with Britain. ... British rule appears to have done far more than what its predecessor regimes and contemporary Indian regimes were able to do. ${ }^{16}$

Whatever British policy, British imperialism was, Mishra believes, evil in its consequences, the effects of British rule outlasting, if not outliving, the British imperialists themselves. Free trade was the least of it: ${ }^{17}$

[The] neo-imperialist assaults on Iraq and Afghanistan served to highlight the actual legacy of British imperialism: tribal, ethnic and religious conflicts that stifled new nation states at birth or doomed them to endless civil war punctuated by ruthless despotisms. ${ }^{18}$

Iraq and Afghanistan were societies wounded by imperialism; and if they are today squalid and violent, the fault is not entirely their own. Something is left over. In this, Mishra is correct. But in nothing else. In 1831, the territory that is now Iraq passed from Mamluk control to Ottoman rule. Signed by Britain and France in 1916, the Sykes-Picot Agreement divided the Ottoman provinces of the Middle East. If the British grabbed what they could, so did the French. The Russians were not far behind, the Sazonov-Paléologue Agreement assigning Turkish Armenia to Imperial Russia. In 1920, the San Remo conference initiated the British Mandate over Palestine, an exercise in imperial rule justified by the assumption that if the British had no obvious right to rule Iraq, the Iraqis had no obvious way in which to rule themselves. The British were rewarded for their troubles by the Iraqi revolt. ${ }^{19}$ The British handed nominal authority over mandatory Iraq to Emir Faisal in 1921, and ostensible independence to the Kingdom of Iraq in 1932. The British, of course, kept their nose in Iraqi affairs well after they had withdrawn their hands. ${ }^{20}$ Their influence did not represent an imperial masterpiece, Iraq, during the 1930s and 1940s, tending, if not tilting, toward Nazi Germany.

The Iraqi monarchy was never a triumph of statecraft, but neither was the Republic of Iraq that followed the July 14 revolution of 1958. Unstable and divided under the Ottomans, Iraq remained unstable and divided under the British, and then under themselves. Whatever the Iraqi tribal, ethnic, and religious conflicts under the monarchy or the republic, they were suppressed or controlled, sometimes by force, often by terror, and, as often, by bribery; they achieved a degree of lurid efflorescence only after the Anglo-American invasion of Iraq. This is no inspiring story, but neither is it one in which the "actual legacies of British Imperialism" played a very obvious role. The morbid conflict between Sunni and Shiite religious communities has smoldered in Islamic life since the Battle of Karbala in 680 . 
To assign to British imperialism in the nineteenth century the conflicts consuming Afghanistan in the twenty-first, is to favor what is remote in history at the expense of what is directly under one's nose. ${ }^{21}$ Afghanistan is today the victim of both American and Soviet imperial incompetence; and the victim, as well, of various tribal insurgencies, fanatical in their exertions, but Islamic in their devotions. ${ }^{22}$ In 1978, the People's Democratic Party of Afghanistan assassinated president Mohammed Daoud Khan, and then murdered his family just to be on the safe side. The promotion of Nur Muhammad Taraki to the presidency provoked rebellion in Nuristan Province. The luckless Taraki was murdered by supporters of prime minister Hafizullah Amin. The Soviets invaded thereafter, protecting the Amin regime by murdering Amin. The Soviets were persuaded to leave the great game when it became clear that they could not win it and had no reason to fight it, a lesson that the United States was slow to learn.

Afghanistan was among the pawed-over states of central Asia; the British, in the nineteenth and the early twentieth centuries, pawing it over again and again, always to the detriment of Afghanistan and seldom to the benefit of the Empire. But those murderous tribal, ethnic, and religious conflicts-they were homemade. ${ }^{23}$

\section{I} N JUSTIFYING HIS denunciation of the British Empire, Mishra appeals to the living and the dead: the righteous consensus on the one hand, and, on the other, various anti-colonial leaders who, Mishra imagines, were once seen jabbing their stiffened index fingers into the retreating chests of offended imperial officials. Some of these anticolonial types had an embarrassing tendency preemptively to reject the party line. Writing at the beginning of the nineteenth century, Ram Mohan Roy was employed by the British East India Company and, his aspirations for Indian independence notwithstanding, understood, even if he did not endorse, British claims of moral superiority: "[Roy] wanted to legitimize Hindu traditions to his European acquaintances by proving that 'superstitious practices which deform the Hindu religion have nothing to do with the pure spirit of its dictates!"'24 The superstitious practices, to which Roy objected, included sati, caste rigidity, polygamy, and child marriages-enough to make any society queasy. ${ }^{25}$ Mahatma Gandhi remains irreproachable. There is no point in further discussing his greatness. But Mishra requires a figure still more deeply embedded in Indian history to make his case against the British. The Bengali writer and Hindu nationalist Swami Vivekananda, if not made to measure is, at least, tailor-made. Having been born Narendranath Datta, Vivekananda underwent a promotion to Swamihood after a spiritual apprenticeship with Swami Ramakrishna. ${ }^{26}$ It is Swami Vivekananda that Mishra regards as India's "most famous nineteenth-century thinker," and it is Vivekananda who "articulated a widespread moral disapproval of the pith-helmeted missionaries of Western civilization."27

Did he? Did he really? There is this:

Intoxicated by the heady wine of newly acquired power, fearsome like wild animals who see no difference between good and evil, slaves to women, insane in their lust, drenched in alcohol from head to foot, without any norms of ritual conduct, unclean ... dependent on material things, grabbing other people's land and wealth by hook or crook ... the body their self, its appetites their only concern-such is the image of the western demon in Indian eyes. ${ }^{28}$

Mishra has wisely provided no source for this quotation. ${ }^{29}$ The words appear in English in Vivekananda's The East and the West (Prachya o Paschatya), which was written originally in Bengali. They do not mean what Mishra suggests they mean. Vivekananda intended to call attention to the distortions that made it impossible for the British and the Indians to see one another clearly. "This is what meets the eye of the European [emphasis added] traveler in India," he wrote:

Devastation by violent plague and cholera; malaria eating into the very vitals of the nation; starvation and semi-starvation as second nature; death-like famine often dancing its tragic dance; the Kurukshetra (battlefield) of malady and misery, the huge cremation ground, strewn with the dead bones of lost hope, activity, joy, and courage; and in the midst of that, sitting in august silence, the Yogi, absorbed in deep communion with the Spirit, with no other goal in life than Moksha [enlightenment]. ${ }^{30}$

The reciprocal image under Indian eyes is of men who, when they were not drenching themselves in alcohol, or drinking it, I suppose, were slaves to women and insane in their lust. ${ }^{31}$ Vivekananda's judgment? "These are the views of observers on both sides-views born of mutual indiscrimination and superficial knowledge or ignorance [emphasis added]."32

Vivekananda was no provincial. He spent years in the United States, where he was widely admired for his handsome presence, his colorful costumes, and his loud voice. His appreciation of the world, if comic, was also cosmopolitan: "For patriotism, the Japanese! For purity, the Hindu! And for manliness, the European! There is no other in the world ... who understands, as does the Englishman, what should be the glory of a man!" 33 If cosmopolitan-he got around-Vivekananda met the world beyond India with the ever-present sense that he was in possession of a culture that, because it was old, was universal. ${ }^{34}$ There is today a rich and preposterous industry of Hindu commentators, of which Deepak Chopra is an example, purporting to see the essentials of quantum mechanics in the Vedic sagas. ${ }^{35}$ This is silly without being sinister. ${ }^{36}$ Vivekanan- 
da's political influence is both. A direct line runs from Vivekananda's Hindu nationalism to Narendra Modi's India, one that Modi himself has cherished and exalted. ${ }^{37}$ Mishra is Modi's critic. He understands the dangers of Hindu nationalism, its fanaticism and its hysteria. He is in these matters no fool. In playing around with Swami Vivekananda, he is playing with fire.

And this is something that Mishra knows. In his review of V. S. Naipaul's India: A Million Mutinies Now, Swami Vivekananda suffers a demotion from India's most famous nineteenth-century thinker to a hysterical religious revivalist:

Mr. Naipaul was also appalled by the prickly vanity of many Hindus who asserted that their holy scriptures already contained the discoveries and inventions of Western science, and that an India revitalized by its ancient wisdom would soon vanquish the decadent West. He was particularly wary of the "apocalyptic Hindu terms" of such 19th-century religious revivalists as Swami Vivekananda, whose exhortation to nation-build through the ethic of the kshatriya (the warrior caste) has made him the central icon of India's new Hindu nationalist rulers. ${ }^{38}$

Like Shiva, Mishra enters combat with many arms.

$\mathrm{H}$ INDUISM IS ONE religious force in the contemporary world; Islam, another. In discussing Paul Berman's Terror and Liberalism, Mishra writes that "After 'trolling the Islamic bookstores of Brooklyn,' he [Berman] offered a genealogy of 'Islamism' that rested almost entirely on his reading of Sayyid Qutb, an ideologue of the Egyptian Muslim Brotherhood." ${ }^{39}$ This suggests that Qutb was no more than a minor Islamic thinker, a crank of sorts and so someone whose tracts might well have been remaindered in a Brooklyn bookstore. This is nonsense. Qutb was, like Vivekananda, a significant theologian, a prolific writer, a man in possession of a system of thought, and, above all, a major influence on Islamic political movements from the Muslim Brotherhood to al-Qaeda. Berman is no Arabic scholar, but some very large portion of Qutb's masterpiece, In the Shade of the Qur'an, is now available in English and in French; and Berman has made himself its master..$^{40}$ This is an achievement. It is plain from what Berman writes that Vivekananda and Qutb are similar, and if they did not offer the public the same face-Vivekananda was a dominating and attractive public man, while Qutb was not, the Egyptians hanging him for his troubles-they did share a universal system of religious anxieties. Like Vivekananda, Qutb had spent time in the United States (in Colorado, of all places), and, like Vivekananda, he was treated cordially. Though he may have been distant and aloof, he must have been cordial in return. But all the while, as his hosts inquired about the pyramid at Giza or the subtle details of Egyptian belly dancing, his cordiality was a cover for a sense of corrosive cultural contempt, a contempt that expressed itself as sexual fastidiousness and distaste. "The American girl is well acquainted with her body's seductive capacity," he wrote. "She knows seductiveness lies in the round breasts, the full buttocks, and in the shapely thighs, sleek legs and she shows all this and does not hide it." It requires no very refined analysis to see that this passage reflects a barely controlled sexual hysteria, one that is ubiquitous in religious life. Saint Jerome found Roman women as horrifying as Qutb found the women of Colorado. And for the same reason: they were unclean.

The way you dress is an index of your secret desires. Your bodice is purposely ripped apart to show what is beneath, and, while hiding what is repulsive, to reveal what is beautiful. You wear stays to keep your breasts in place, and confine your body in a girdle. Sometimes you let your shawl drop so as to lay bare your white shoulders. ${ }^{42}$

Mishra is prepared to use Vivekananda for polemical purposes. What he has to say, after all, is obscure in the knowledge ecosystems of the West. He can be offered as a nineteenth-century stalwart of Indian independence. No one at the Guardian is about to read his collected works, and not Mishra either. But between Vivekananda and Qutb quivers a single vibrating nerve. In contemplating his own "strange power," Vivekananda attributed it to his ascetic renunciations: "never once in my life did I allow myself to have even one sexual thought." ${ }^{43}$ It is an endearing remark, but one that defeats itself. Never once? Nevertheless, as one observer comments,

the Swami showed himself to be quite a female watcher. He was both keen and curious about the figures and fashions of the American women. In a letter to his monastic brother he observed that the American women belonged to the race of the titans (birochaner jat) and that they were extremely body-conscious and thus "always keep their body clean and made up." ${ }^{44}$

There it is - that old and almost universal religious sense that the right ordering of the state depends on the control of female sexuality.

"When unrighteous disorder prevails, the women sin," the Bhagavad Gita reminds us, "and are impure; and when women are not pure, Krishna, there is disorder of castes, social confusion." ${ }^{45}$

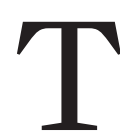
HE BRITISH WITHDREW from India in August of 1947. The Raj was at an end, India divided. The communal riots that followed left millions dead. The Pakistani writer Saadat Hasan Manto was stupefied by what he saw and shocked by what it meant. "Human beings in both countries," he wrote, "were ... slaves of religious passions, slaves of animal instincts and barbarity." ${ }^{46}$ Manto's short 
stories are chilling and often gruesome. They meet their subject honestly. In this remark, Manto has succumbed to the weakness of avoiding judgment by deflecting responsibility. No one was a slave to anything-not in Bali, not in Cambodia, not in China, not in India, not in Rwanda, not in Yugoslavia, not anyone, not anywhere. In Sarfraz Manzoor's review of Manto's short stories-the same flaw:

The borderline was arbitrary and artificial-established in haste by a British barrister called Sir Cyril Radcliffe-and in trying to slice India along religious lines, it [emphasis added] turned former Muslim, Hindu and Sikh friends and neighbors against each other. ${ }^{47}$

How it could do any such thing, Manzoor does not say. It is in an essay entitled "Bumbling Chumocrats" that Mishra repairs to the same theme, and to the same effect. He sees what has happened: he is unwilling to ask why it did. ${ }^{48}$ Cyril Radcliffe again takes the blame and so takes the fall. "Radcliffe," Mishra writes, "was entrusted with the task of drawing new boundaries of a country he had never previously visited":

Dividing agricultural hinterlands from port cities, and abruptly reducing Hindus, Muslims and Sikhs on either side of the new border to religious minorities, Radcliffe delivered a plan for partition that effectively sentenced millions to death or desolation while bringing him the highest-ranked knighthood. ${ }^{49}$

This is again cant. Was it Radcliffe's plan that sentenced millions to death or desolation $?^{50}$ In the New Yorker essay on which "Bumbling Chumocrats" is based, Mishra writes that British policy altered Indian self-perceptions, quoting Alex von Tunzelmann in his support: "Many Indians," von Tunzelmann wrote, "stopped accepting the diversity of their own thoughts..." The British policy was what it was, but if Indians stopped accepting the diversity of their own thoughts, it follows that some portion of that responsibility must be Indian. The British were not rioting throughout India. The Indians did it to themselves and they did it by themselves. This is a point that Tunzelmann herself makes:

Beyond the leaders, every ordinary person who picked up a weapon and used it against his neighbor bore responsibility for his own action. For every rape, there was a rapist; for every murder, there was a murderer. ${ }^{51}$

It is a pity that Mishra did not think to quote these words.

AVING SERVED AS the title of this collection, "Bland Fanatics" serves again as the title of its most important essay. It is here that Mishra means to coordinate his ideas about liberalism and colonialism. He is opposed to the second, dubious about the first-dubious because liberalism regards the "contingent achievements of our culture as the final form and norm of human existence." 52 These are words intended to make a case, but it is a case that Mishra cannot close.

"We should acknowledge the religious sources of liberal secularism," Larry Siedentop remarked in the Financial Times. "That would strengthen the West, making it better able to shape the conversation of mankind.. ${ }^{53}$ It is the note of presumption to which Mishra objects, the idea that the West is in a position to shape the greater gabble, and having shaped it, entitled to ignore whatever is left over. The remainder of his essay Mishra devotes to showing that any number of writers have turned a deaf ear to "mankind's many other [emphasis added] conversations with itself.",54

Not me, I must say. I am all ears. Yet scholarly access to the conversations of mankind is almost always difficult to achieve, and, once achieved, often of interest only to specialists. These are not considerations that Mishra finds compelling. He is committed to the greatness of the greater gabble. Did Ferguson argue that the scientific revolution was wholly Eurocentric? If so, he has disregarded "contemporary scholarship about Muslim contributions to Western science, most recently summarized in George Saliba's Islam and the Making of the European Renaissance." 55 If so? Not so. Saliba observed that the true point of Islamic scientific decline was the sixteenth and not the twelfth century. This is hardly a daring thesis. The Timurid Renaissance lasted, at least, until the decline into desuetude of Ulugh Beg's magnificent observatory in Samarkand. ${ }^{56}$ By 1449 , the observatory was in ruins. Saliba does entertain the possibility that Nicolaus Copernicus may have been influenced by Ibn al-Shatir, a fourteenth-century Damascene astronomer. ${ }^{57}$ Perhaps he was. Still, Saliba offered no plausible route of transmission between Ibn al-Shatir and Copernicus, who was, in any case, unable to read Arabic. ${ }^{58}$ Thereafter, an increasing darkness came over Islamic astronomy. In 1580, the great Royal Islamic Observatory in Istanbul was destroyed on orders of Sultan Murad III. ${ }^{59}$

The dogs barked; the caravan moved on.

In writing about Alan Ryan's On Politics: A History of Political Thought: From Herodotus to the Present, Mishra finds in Ryan a living embodiment of conversational deafness. Were he only to have gotten the wax out of his ears, Ryan might well have attended to "Chanakya, Mencius, Ashoka or al-Ghazali, or of traditions of political thought older than Greece's." ${ }^{\prime 0} \mathrm{I}$ have long championed wax removal, but Ryan is writing about a particular tradition of political thought, one that has its own distinctive identity and history. He says so himself, and to accommodate the deaf, I am persuaded that he would be willing to sign so as well. ${ }^{61}$ "The tradition this book explores," Ryan writes, "began when Greek thinkers saw that they governed themselves in a way their Asiatic neighbors did not." ${ }^{62}$ It is a tradition 
to which Chanakya, Mencius, Ashoka, or al-Ghazali are remote and, what is more, Chanakya, Mencius, Ashoka, and al-Ghazali are themselves too heterogeneous as thinkers to cohere as anything more than a set. I can just imagine the suave and affable Mencius ${ }^{63}$ trying to get a word out of the glowering al-Ghazali, so stupefied by skeptical doubts that "God put a lock on his tongue." ${ }^{64}$

Chanakya's Arthaśāstra is something like a fourth-century BCE handbook for rulers, ${ }^{65}$ a weak solution of Niccolò Machiavelli's The Prince and Baldassare Castiglione's The Book of the Courtier, with much valuable advice about detecting poisons, aborting conspiracies, and handling spies. ${ }^{66}$ In Chapter XII, the Arthaśästra discusses the "Creation of Wandering Spies," the poisoners among them,

such as a sauce-maker (súda), a cook (arálika), procurer of water for bathing (snápaka) shampooer, the spreader of bed (ástaraka), a barber (kalpaka), toilet-maker (prasádaka), a water-servant; servants such as have taken the appearance of a hump-backed person, a dwarf, a pigmy (kiráta), the dumb, the deaf, the idiot, the blind; artisans such as actors, dancers, singers, players on musical instruments, buffoons, and a bard; as well as women shall espy the private character of these officers. ${ }^{67}$

Hunchbacks, dwarfs, pigmies, the deaf and dumb, idiots, buffoons, and women? One hopes this is no downward progression. Who knew that mankind's other conversations had once strayed so far from contemporary standards of delicacy?

In its general observations, the Arthaśāstra is somewhat less provocative: “The observance of one's own duty leads one to Svarga and infinite bliss (Ānantya). When it is violated, the world will come to an end owing to confusion of castes and duties." ${ }^{\circ 8}$

Ashoka ruled over the greater part of India during the third century BC, and was notable for his embrace of Buddhism after being revolted by the dead after the Battle of Kalinga. ${ }^{69}$ His wisdom he inscribed on pillars throughout India. "Dhamma is good," Ashoka wrote. "And what is Dhamma? It is having few faults and many goods deeds, mercy, charity, truthfulness and purity." ${ }^{\prime 0}$ This is interesting enough and even readers remote from ancient Indian thought might appreciate the advantages of Dhamma. Ryan's interests are otherwise. He says so explicitly. "Political thought as we understand it began in Athens." And we do not understand political life in terms of Dhamma.

Willst du immer weiter schweifen?

Sieh, das Gute liegt so nah.

Lerne nur das Glück ergreifen.

Denn das Glück ist immer da. ${ }^{71}$

The figure to whom Mishra might properly have called attention is Abu al-Biruni, an eleventh-century poly- math of overpowering curiosity, whose collected works, running to 1,300 folio pages, cover mathematics, astronomy, physics, linguistics, and a dozen other subjects, and include an extraordinary account of Indian society, the Kitāb al-Hind. In it he observed, with some equanimity, that among Hindus, Muslims were thought low, impure, cunning, grasping, and cruel.

This is, at last, something worth hearing.

$\mathrm{I}$ $\mathrm{N}$ HIS INTRODUCTION and in an essay first published in 2009 entitled "The Culture of Fear," Mishra proposes to assess, and, of course, condemn, "intellectual Islamophobia," then, as now, in great demand but short supply. Christopher Caldwell's Reflections on the Revolution in Europe, Mark Steyn's America Alone, and Bruce Bawer's While Europe Slept, as well as his subsequent Surrender, all fall under Mishra's stern gaze. Look here, he advises in referring to attacks on the World Trade Center and the Pentagon:

A small group of criminals and fanatics did not pose a mortal threat to the most powerful and wealthy societies in history. Nevertheless, the maniacal cries of "Allahu Akbar" were met by a louder drumbeat of "Western values" and confidence-building invocations of the West's apparent quintessence, such as the Enlightenment. ${ }^{72}$

These are remarks that today seem curiously ill at ease, drumbeats and invocations notwithstanding, and appropriate neither to their moment or ours. The terrorists were never heard crying Allahu Akbar, whether maniacally or in a low murmur, no doubt because they were too busy flying the planes that they had hijacked; and whatever one thinks of George W. Bush, he is hardly a man one might expect to see chewing his lip as he considers the distinction between the Scottish and the French Enlightenments.

Caldwell, Steyn, and Bawer are soft targets. Easy to hit, they do not hit back. "So what if Muslims account for only 3 to 4 per cent of the EU's total population of 493 million?" Mishra asks in exasperation. ${ }^{73}$ A secret must now be imparted. I am in agreement with Mishra. So what? But our insouciance, considering the thing now as a limited partnership-very limited-needs to be balanced against the relevant facts; and while Muslims account for only three to four percent of the European Union's total population, this is to massage a ratio by inflating its denominator. In France, first and second generation Maghreb immigrants now number roughly six percent of France's population. This is no negligible figure. ${ }^{74}$ No one knows the extent or depth of the change in prospect. Caldwell is surely right when he observes that "minorities can shape countries."75 Acting as a one-man minority, Gavrilo Princip initiated the sequence of events leading to World War I. ${ }^{76}$

Mishra's objurgations have a certain fustiness. His assurances that Islamic terrorism does not pose "a mortal 
threat to the most powerful and wealthy societies in history," if true at all, is irrelevant as well. ${ }^{77}$ The threat is slow acting, unpleasant, and almost impossible to counter.

This is the situation in France today. ${ }^{78}$

Marine Le Pen is a blonde rather than a bland fanatic, but blonde or bland, she remains perennially the star of her own production of Blonde Ambition-le Rassemblement National. Mishra finds it all distasteful. He is not able to say why. The National Front in France,$^{79}$ Mishra observes,

advanced the right to be culturally distinctive, and to exclude outsiders who would radically transform white, Christian Europe. In this vision, cultures rather than biologically defined races were presented as exclusive and unchanging across time and place, with cultural difference treated as a fact of nature ... that we ignore at our peril. Preferring our own kind, we apparently belong, in defiance of human history, to an immutable community bound by its origins to a specific place, and should have the right to remain distinctive. ${ }^{80}$

The words "an immutable community" are intended to suggest a very great absurdity, the more so since what is claimed is in "defiance of human history." But in Europe, at least, a sense of ethnic identity goes back to the medieval era. Writing about Parisian student life in the twelfth century, the chronicler Jacques de Vitry observed that

[students] affirmed that the English were drunkards, and had tails; the sons of France proud, effeminate and carefully adorned, like women. They said that the Germans were furious and obscene in their feasts; the Normans, vain and boastful; the Poitevins, traitors and always adventurers. The Burgundians they considered vulgar and stupid. The Bretons were reputed to be fickle and changeable ... The Lombards were called avaricious, vicious and cowardly; the Romans seditious, turbulent and slanderous; the Sicilians slanderous and cruel; the inhabitants of Brabant, men of blood, incendiaries, brigands and ravishers; the Flemish fickle, prodigious, gluttonous... ${ }^{81}$

That the French have long been considered proud, effeminate, and carefully adorned is not evidence that these traits are immutable. A further inference is required. What de Vitry's narrative does show is that ethnic identities have a history, a shape in time and space. If they are not immutable, neither are they infinitely elastic. ${ }^{82}$

These facts are difficult entirely to accommodate and no one has succeeded in accommodating them entirely. Not Mishra either:

For many of these Muslim aspirants for full and equal citizenship, the urgent questions are whether the oldstyle liberalism of many European nation states, which has traditionally assumed cultural homogeneity, can accommodate minority identity, and whether majority communities in Europe can tolerate expressions of cultural and religious distinctiveness [emphasis added]. A part of the secular intellectual priesthood, which cannot survive without its theological opposition between the Enlightenment and Islam, thinks not. In 2004, France's ban on the wearing of headscarves in public schools bluntly clarified that Muslims will have to renounce all signs of their religion in order to become fully French. ${ }^{83}$

"Old-style liberalism" is a phrase that means very little pending an elaboration of old, style, and liberalism..$^{84}$ No European state ever demanded complete cultural homogeneity because no European state ever succeeded in defining it. Cultural homogeneity and a decent commitment when in Rome to do as the Romans do are quite different concepts. He is prepared to welcome you as French, the exuberant Jean-Marie Le Pen remarked, "Si vous êtes fidèles à la France, si vous l'aimez, si vous adoptez ses lois, ses mours, sa langue, sa façon de penser, en un mot, si vous vous intégrez complètement à elle." ${ }^{85}$ Unlike Charles de Gaulle, Le Pen was also prepared to see Maghrebian Muslims as fully a part of the French polity. A sense of cultural homogeneity is remote.

Mishra's real point-his only point-comes down to a question. Can the French tolerate expressions of cultural and religious distinctiveness? It all depends. Who in France would scruple at the veil if the veil were all that provoked scruples? The French are unwilling to accommodate anti-Semitism of the grossest kind, a vicious contempt for the French state and its secular commitments, religious obscurantism, and murder in the name of Islam. ${ }^{86}$ These are not matters of cultural or religious distinctiveness. The French regard them as intolerable. ${ }^{87}$

So do I.

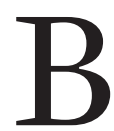
отн IN "The Culture of Fear" and variously throughout Bland Fanatics, Mishra is minded to pursue the relationship between purity and state formation. He is right to do so. The connection is dark, deep, disturbing. ${ }^{88}$ Quoting Tony Judt, Mishra writes that

Genocide during the Second World War, followed by ethnic cleansing, was what finally resolved Europe's long-standing minority "problem," blasting flat ... "the demographic heath upon which the foundations of a new and less complicated continent were then laid." In Europe's largest migrations of refugees, some 13 million ethnic Germans fled Poland, Czechoslovakia, Hungary and Romania after the war. The eviction of other ethnic groups (Poles, Czechs, Slovaks) brought many countries closer to filling the Versailles ideal of national homogeneity. ${ }^{89}$

The image of a blasted heath, if it succeeds at all, succeeds only too well. Europe in 2021 is less diverse than 
it was in 1914-less diverse in its ethnic, social, political, and class structures, and less diverse in its architecture, art, literature, science, philosophy ${ }^{90}$ but less diverse, as well, in the number of its aggressive and lunatic political movements, crackpot ideologies, and mystic imbecilities generally. It is easy to forget that Hitler was but one of a number of rabble rousers, successful only because he better roused the rabble. The European Union is bland by design, perhaps, but bland in fact. The historian may not think this a very bad thing.

Judt and Mishra regard the destruction of European Jewry and the expulsion of central Europe's ethnic Germans as the flash of the same terrible whip. ${ }^{91}$ They are persuaded that the hands that held that whip were in service to the Versailles ideal of national homogeneity. He who wills the ends wills the means. ${ }^{92}$

The facts are rather more complicated. For a very long time, historians assigning blame for the outbreak of war in 1914 took as their starting point Élie Halévy's declaration that

[w]e should ask, not who, but what [emphasis original] was responsible for the three declarations of war; and the answer should be: "The rotten conditions of the Austro-Hungarian Empire, the fact that the revolutionary principle of nationality was at work within its limits, and that it was about to break up into a number of independent States." ${ }^{93}$

This has now changed. The Empire has undergone a posthumous improvement, historians assigning it many of the virtues that its subjects always believed it possessed. It was stable, fair, well-administered, tolerant, and decent.

In The Habsburg Empire, Pieter Judson argued that whatever the ostensible yearning for national purity, the states that followed the Hapsburg Empire were themselves little empires, fractious within themselves, and so impure. Every state after 1918

was a Vielvölkerstaat, whose survival demanded the integration of multi-ethnic populations, the successful-if often authoritarian-attachment of peripheries to centers, and the development of a positive sense of shared identification, even among people who claimed to belong to the same nation. Far from marking the end of the Vielvölkerstaaten, 1918 could be said to have witnessed their proliferation. ${ }^{94}$

The striking contrast between the Versailles ideal of national homogeneity and the rabble of little empires throughout central Europe might suggest that the ideal was unachievable. ${ }^{95}$

The perfect truth.

No entity without identity, W. V. O. Quine once remarked. Sets are identical if they share the same mem- bers. Simple, sane, sensible. Thereafter everything goes dark. Identity is an imperious demand and one not much amenable to definition. "We shall call 'ethnic groups," Max Weber remarked,

those human groups that entertain a subjective belief in their common descent because of similarities of physical type or of customs or both, or because of memories of colonization or migration. ${ }^{96}$

Sicilians are slanderous and cruel, as de Vitry observed in the thirteenth century. The inference goes from similarities among Sicilians to a subjective belief in common descent. And thereafter any pretension to analytical refinement disappears. How might common descent be justified? Memory and court records may take a Sicilian to his great-grandparents, but beyond that, there is only the turbid ebb and flow of the Mediterranean world. An appeal to genetic diversity leads nowhere. There is no discernible coincidence between ethnic and genetic identity. Berlin under Nazi rule was no more genetically homogeneous than the Bronx, and although China is genetically quite homogeneous, there are more than fifty recognized ethnic groups within China today.

An ethnic identity is, as Weber understood, something artificial. It is made up. An inference is required from language, skin color, habit, geography, or shared memory to the presumption of common ancestry; and if an inference, then a choice. All human beings are similar in some respect. If a choice, by what standard? There are nine and sixty ways of constructing tribal lays, and every one of them is right. This is something that Mishra recognizes:

The fervour of the ideologue manqué made no room for the sober fact that almost every nation state harbours a disaffected and volatile minority, whose size varies constantly in inverse relation to the alertness, tact and wisdom of the majority population..$^{97}$

If this is so, what remains of the image of central Europe as a blasted heath? Poland is today genetically homogeneous, pure in virtue of mass murder and ethnic expulsions. No one could mistake genetic homogeneity in Poland for cultural or political homogeneity. ${ }^{98}$ Those pure Polish Poles are today divided-polarized, in fact. The disaffected and volatile minorities in Europe are today based on class, economic, political, racial, religious, and sexual distinctions. This hardly means that ethnic distinctions have disappeared.

It means their importance has diminished.

Between Mishra's decent and generous commitment to multiculturalism, and his unwillingness, or inability, to follow his argument to its end, is an area of unease. What a century of conflict has demonstrated is that every form of presumptive purity is an unstable bond of state formation, 
one incapable of dissolving, or even constraining, the fractiousness of life itself.

I N 1756, Samuel Johnson published a review of Thomas Blackwell's Memoirs of the Court of Augustus. "I know not why anyone but a schoolboy in his declamations," he wrote, "should whine over the commonwealth of Rome, which grew great only by the misery of the rest of mankind." ${ }^{99}$

Tacitus assigns the same sentiments to a tribal chieftain. It is a speech that Johnson surely knew:

These plunderers of the world [the Romans], after exhausting the land by their devastations, are rifling the ocean: stimulated by avarice, if their enemy be rich; by ambition, if poor; unsatiated by the East and by the West: the only people who behold wealth and indigence with equal avidity. To ravage, to slaughter, to usurp under false titles, they call empire; and where they make a desert, they call it peace. ${ }^{100}$

In an oration entitled "Regarding Rome," the Greek rhetorician Aelius Aristides offered his audience a quite different view of imperial power:

If one considers the vast extent of your empire he must be amazed that so small a fraction of it rules the world, but when he beholds the city and its spaciousness it is not astonishing that all the habitable world is ruled by such a capital ... Your possessions equal the sun's course ... You do not rule within fixed boundaries, nor can anyone dictate the limits of your sway ... Whatever any people produces can be found here, at all times and in abundance ... Egypt, Sicily, and the civilized part of Africa are your farms; ships are continually coming and going. ${ }^{101}$

"The whole world prays," Aristides added, "in unison that your empire may endure forever."

The same ledger may be drawn up with respect to the British Empire, but with different entries. The British left India, but their institutions remained. They are in place today: the extraordinary railway system, the irrigation network, the common law, the British administrative system, the peculiar nature of British political ideals. If we cannot easily or confidently judge the Roman Empire after 2,000 years, who on earth would think it easy to judge the British Empire after one hundred years?

The truth about the Roman Empire is, as one might expect, very large. ${ }^{102}$ So, too, the truth about the British Empire. In his Autobiography of an Unknown Indian, the well-known Bengali writer Nirad Chaudhuri began his book with a most Aristidean dedication, one that Naipaul calls "staggering but appropriate."103

To the memory of the British Empire in India, Which conferred subjecthood upon us,
But withheld citizenship.

To which yet every one of us threw out the challenge:

"Civis Britannicus sum"

Because all that was good and living within us

Was made, shaped and quickened

By the same British rule. ${ }^{104}$

Chaudhuri was vilified for his dedication by Indian politicians and writers, who failed to grasp entirely its irony. He repaired to England in 1972; he was welcomed and even feted. He never returned to India and died an old man. Dilexi iustitiam et odivi iniquitatem propterea morior in exilio.

Naipaul, in reviewing Philip Woodruff's The Men Who Ruled India, recognizes, as Mishra does not, the British Book of Accounts: "Woodruff," he writes, "has written with sad, Roman piety of the British achievement. It was a tremendous achievement; it deserved this piety." In assessing the Raj, Naipaul adds, "There is always an embarrassment, of racial arrogance on the one hand, and of genuine endeavour on the other. Which is the reality? They both are and there is no contradiction.,"105

How could it be otherwise?

David Berlinski is an American writer.

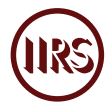

1. "Who in full security, undertakes the defense of the assassination of Caesar, and declares his resolution to speak plain." Samuel Johnson, "Review of Thomas Blackwell's Memoirs of the Court of Augustus," in Samuel Johnson: 21st-Century Oxford Authors, ed. David Womersley (Oxford: Oxford University Press, 2018), 533.

2. Pankaj Mishra, Bland Fanatics: Liberals, Race and Empire (New York: Farrar, Strauss \& Giroux, 2020). The table of contents: the introduction; "Watch This Man" (on Niall Ferguson); "The Culture of Fear" (on Islamophobia); "The Religion of Whiteness" (the First World War and colonial combatants); "The Personal as Political" (on Salman Rushdie); "The Man of Fourteen Points" (on Woodrow Wilson); "Bland Fanatics" (on liberalism and colonialism); "The Age of the Crisis of Man" (an extended review of Mark Greif's book of that name); "Free Markets and Social Darwinism in Mumbai" (an extended review of Katherine Boo's Behind the Beautiful Forevers); "The Lure of Fascist Mysticism" (on Jordan Peterson); "What Is Great About Ourselves" (on liberalism); "Why Do White People Like What I Write?” (on Ta-Nehisi Coates); "The Mask It Wears" (on Samuel Moyn, human rights, and neoliberalism); "The Final Religion” (on Alexander Herzen); "Bumbling Chumocrats" (on Brexit and British elites); "The Economist and Liberalism" (on the journal and its history); and "England's Last Roar" (on Enoch Powell). 
3. Mishra, Bland Fanatics, 4.

4. Mishra, Bland Fanatics, 5.

5. Reinhold Niebuhr, The Structure of Nations and Empires (New York: Scribner, 1959), 298. For a review, see Henry Roberts, "Recent Books on International Relations," Foreign Affairs 38, no. 1 (1959): 146-62, doi:10.2307/20029407.

6. The phrase "prehensile bottoms" is best passed over in silence. Mishra, Bland Fanatics, 200. A great mixer of metaphors, Mishra sees his bland fanatics

[i]ncarnated as liberal internationalists, neocon democracy promoters and free-market globalizers, [where] they would blunder through a world grown more complex and intractable, and help unravel large parts of Asia, Africa and Latin America before sowing political chaos in their own societies.

Mishra, Bland Fanatics, 2. To have simultaneously blundered, unraveled, and sown is a remarkable achievement. When Mishra writes (ironically) that Indian democracy "had acquired deep roots in Indian soil, fertilizing it for the growth of free markets," he is promoting a novel horticultural doctrine. Mishra, Bland Fanatics, 4.

7. Cyril Connolly, Horizon: A Review of Literature and Art 20, no. 120-21 (1949): 362. "It is closing time in the gardens of the West and from now on an artist will be judged only by the resonance of his solitude or the quality of his despair." It is too bad that Connolly spoiled his own exquisite metaphor with gibberish about the resonance of his solitude and the quality of his despair.

8. Mishra, Bland Fanatics, 29. Mishra has gotten Benjamin's remark slightly wrong. "There is no document of civilization," Benjamin wrote, "which is not at the same time a document of barbarism." (Walter Benjamin, "Theses on the Philosophy of History," in Illuminations: Essays and Reflections, ed. Hannah Arendt, trans. Harry Zohn (New York: Schocken Books, 1969), 256.) The editors, in turn, have gotten their translation wrong, too. The original reads, "Es ist niemals ein Dokument der Kultur, ohne zugleich ein solches der Barbarei zu sein." The French, as Norbert Elias has remarked, do civilization; the Germans Kultur. See Norbert Elias, The Germans: Power Struggles and the Development of Habitus in the Nineteenth and Twentieth Centuries (Cambridge: Polity Press, 1996). Had Benjamin wished to appeal to civilization he would have written Zivilisation. Jeffrey Herf argues that Oswald Spengler, Carl Schmitt, Ernst Jünger, and Martin Heidegger-what a crew!-successfully "removed technology from the world of Enlightenment reason, that is, of Zivilisation, and placed it into the language of German nationalism, that is, of Kultur." See his Reactionary Modernism: Technology, Culture and Politics in Weimar and the Third Reich (Cambridge: Cambridge University Press, 1986), 224.

9. In the knowledge ecosystems that Mishra favors, a denunciation of British imperialism is now universally obligatory and a defense of colonialism unthinkable. I wish this review to be understood as a preemptive apology for remarks that I would have made had I had the thoughts that I might have had. See Bruce Gilley, "The Case for Colonialism," Academic Questions (Summer 2018). This essay was originally published as "The Case for Colonialism," Third World Quarterly (2017), doi:10.1080/01436597.2017.1369037, and then withdrawn. The author is now, I presume, under the US government's witness protection program.

10. Having defended Germany's position in the First World War, Ferguson would, of course, be right at home doing so. See the following note.

11. Mishra, Bland Fanatics, 5. Mishra has based his assessment on Ferguson's popular book, Empire: How Britain Made the Modern World (London: Penguin, 2012). In doing so, he has attended to Mr. Hyde at the expense of Dr. Jekyll. He repeats the mistake in discussing Ferguson's The Pity of War (London: Penguin, 2012). Ferguson is a powerful and professional historian and both books are backed by serious research. In the first case, see Niall Ferguson "British Imperialism Revisited: The Costs and Benefits of 'Anglobalization," Historically Speaking 4, no. 4 (2003): 21-27; and in the second, "Germany and the Origins of the First World War: New Perspectives," Historical Journal 35, no. 3 (1992): 725-52, doi:10.1017/S0018246X0002608X.

12. See John Gallagher and Ronald Robinson, "The Imperialism of Free Trade," Economic History Review 6, no. 1 (1953): 1-15, doi:10.2307/2591017. This remains the reference from which most later discussions flowed, John Gallagher and Ronald Robinson arguing (very broadly, I must say) for the continuity of British policies before and during the Raj and the importance of Britain's informal imperial agenda. With the publication of this essay, interest in J. A. Hobson's thesis, amplified by Vladimir Lenin and repeated credulously by Hannah Arendt, that imperialism was nothing more than the consequence of western capital bloat, began, at long last, to fade. See John Atkinson Hobson, Imperialism: A Study (London: George Allen \& Unwin, 1902).

13. See Jeremy Black, Imperial Legacies: The British Empire around the World (New York: Encounter Books, 2019), but see as well Priya Satia, Time's Monster: How History Makes History (Cambridge, MA: The Belknap Press, 2020), for quite another point of view. For a serene and untroubled appreciation of the British Empire, see Robert Tombs, "In Defense of the British Empire,” The Spectator, May 8, 2020. See, as well, Lawrence James, The Rise and Fall of the British Empire (New York: Saint Martin's Press, 1984).

14. See Lance Davis and Robert Huttenback, "The Political Economy of British Imperialism: Measures of Benefits and Support," Journal of Economic History 42, no. 1 (1982): 11930, doi:10.1017/s0022050700026966. From the abstract:

The paper provides new evidence on the debate over the decision of the British to invest in empire in the period of 1860-1914. An examination of the flow of symbolic cap- 
ital indicates that the Empire was not a major recipient until the end of the period. The largest transfers went to the "rest of the world" although a surprisingly large fraction was absorbed domestically. A study of the profits of British firms operating at home, in the Empire, and abroad shows that while the Empire was relatively very profitable in the years before 1880, domestic returns were higher from that date until the end of the Boer War. Moreover, those domestic returns were also higher than foreign from the mid-1870s to the mid-1880s and again throughout the 1890s. Finally, the evidence indicates that empire returns were as high as they were only because of substantial social subsidies from the British. The imperial experience could therefore be viewed more as a redistribution of income within the United Kingdom than as a transfer from the empire to the mother country.

15. Ferguson, "British Imperialism Revisited," 23.

16. Tirthankar Roy, The Economic History of India, 1857-1947 (Oxford: Oxford University Press, 2000), 257. "Scholarship continues along the imperialism-underdevelopment axis," Roy wrote two years later,

albeit on a smaller scale than in earlier years. But this stance looks increasingly dated and disoriented, especially at a time when economic liberalization in India is drawing upon the tenets of classical political economy on which British policy in India was founded.

See Tirthankar Roy, "Economic History and Modern India: Redefining the Link," Journal of Economic Perspectives 16, no. 3 (2002): 109-10.

17. For a quite different account of protectionism and free trade, see Ha-Joon Chang's very influential, Kicking Away the Ladder: Development Strategies in Historical Perspective (London: Anthem Press, 2002). This is the book Mishra should have cited.

18. Mishra, Bland Fanatics, 11. The words "the actual legacy of British Imperialism" suggest that Mishra has considered the four hundred years during which the British Empire encompassed, or infiltrated, Afghanistan, Antigua and Barbuda, Australia, the American colonies, the Bahamas, Bahrain, Barbados, Belize, Botswana, Brunei, Canada, Cyprus, Dominica, Egypt, Eswatini, Fiji, Gambia, Ghana, Grenada, India, Iraq, Jamaica, Jordan, Kenya, Kiribati, Kuwait, Lesotho, Malawi, Malaysia, Maldives, Malta, Mauritius, Myanmar, Nauru, New Zealand, Nigeria, Pakistan, Qatar, Saint Kitts and Nevis, Saint Lucia, Saint Vincent and the Grenadines, the Seychelles, Sierra Leone, the Solomon Islands, South Africa, Sri Lanka, Sudan, Tanzania, Tonga, Trinidad and Tobago, Tuvalu, Uganda, the United Arab Emirates, Vanuatu, Yemen, Zambia, and Zimbabwe. Has he? What a question. Of course not.

19. See Reeva Spector Simon and Eleanor Tejirian, eds., The Creation of Iraq, 1914-1921 (New York: Columbia University Press, 2004).
20. See Ritchie Ovendale, "Past or Present Middle East?" International History Review 20, no. 3 (1998): 618-32, doi:10.108 0/07075332.1998.9640837. Faisal was, in any case, under no illusions about Iraq:

An Iraqi people does not yet exist; what we have is throngs of human beings lacking any national consciousness or sense of unity, immersed in religious superstition and traditions, receptive to evil, inclined toward anarchy and always prepared to rise up against any government whatsoever.

Memo as translated by Ofra Bengio, "Faysal's Vision of Iraq: A Retrospect," in The Hashemites in the Modern Arab World: Essays in Honour of the Late Professor Uriel Dann, eds. Asher Susser and Aryeh Shmuelevitz (London: Frank Cass, 1995), 146. After Faisal's death, Edmund Ghareeb remarked, "The British were able to undermine the government and the monarchy by constantly putting pressure on them to serve Britain's interests." This is, of course, true; it is also unsurprising, and for this reason, uninteresting. Quoted in Jonathan Kandell, “Iraq's Unruly Century," Smithsonian (May 2003). See as well Edmund Ghareeb and Beth Dougherty, Historical Dictionary of Iraq (Maryland: The Scarecrow Press, 2004).

21. Christian Tripodi, writing in "Grand Strategy and the Graveyard of Assumptions: Britain and Afghanistan, 1839-1919," Journal of Strategic Studies 33, no. 5 (2010): 701-25, doi:10.1 080/01402390.2010.498252, makes the interesting, if utterly implausible, claim that British grand strategy in Afghanistan was correct in its assumptions and relatively successful in its applications. With those standards of success in force, it is no wonder that Britain lost its empire.

22. See Olivier Roy, L’Afghanistan: Islam et modernité politique (Paris: Le Seuil, 1985). Mishra is stern in criticizing nineteenth-century British imperialism; but throughout this volume, he has nothing whatsoever to say about nineteenth-century Russian imperialism, and one would never know the extent to which nineteenth-century British strategy in, say, Afghanistan was influenced by Russian imperialism and vice versa. See, as well, Gilles Kepel, Jihad: The Trail of Political Islam (Cambridge: Belknap Press, 2002). The conflict between Kepel and Roy is, in Paris, a recognized spectator sport.

23. See Edgar O'Ballance, Afghan Wars 1839-1992: What Britain Gave Up and the Soviet Union Lost (London: Brassey's, 1993).

24. A. Jesintha Vilveena, "Role of Raja Rammohan Roy in Social and Religious Reform Movements," International Journal of Management and Social Science Research Review 1, no. 44 (2018): 49. The original quote from Roy appears in Rajah Rammohun Roy, Translation of Several Principal Books, Passages, and Texts of the Vedas, and of Some Controversial Works on Brahmunical Theology (London: Parbury, Allen \& Company, 1832), 4.

25. Brahendra Bandyopadyay, Rommohan Roy (London: University Press, 1933), 351. The British historical response? 
The Bengali Sati Regulation Act, 1829; the Hindu Widows' Remarriage Act, 1856; the Female Infanticide Prevention Act, 1870; and the Age of Consent Act, 1891.

26. Swami is an honorific-teacher, rabbi, guru, and, all too often, sex offender.

27. Mishra, Bland Fanatics, 21. "Pith-helmeted missionaries of western civilization" is Mishra's gaudy invention. Vivekananda would never have used such language, and, in fact, he never did. The British in India were not missionaries nor did they see themselves as representatives of Western civilization. They were, after all, British imperialists. See Parthasarathi Gupta, "Cultural Confrontations: Review of Tapan Raychaudhuri, Europe Reconsidered: Perceptions of the West in Nineteenth Century Bengal," in The Book Review (n.d.). The moral disapproval that Mishra evokes was not quite as widespread as Mishra suggests. Neither Bhudev Mukhopadhyay nor Bankimchandra Chattopadhyay was disposed to reject British rule in India across the board; and Swami Vivekananda's indignation was very often a matter of envious admiration. The British got things done; the Indians, not so much.

28. Vivekananda, quoted in Mishra, Bland Fanatics, 21. See The Complete Works of Swami Vivekananda: Mayavati Memorial Edition, 7th edn. (Calcutta: Advaita Ashrama, 1959), a collection that does not appear to be complete, the more so since it does not contain the quoted remarks. Swami Vivekananda may be as important a figure as Mishra claims; but, if so, it is appalling that no complete, consistent, annotated, and properly edited version of his work exists in English-or in any other language, so far as I can determine.

29. Mishra used the same quotation in From the Ruins of Empire: The Intellectuals Who Remade Asia (New York: Farrar, Straus \& Giroux, 2012), 36. His reference? Tapan Raychaudhuri, Europe Reconsidered: Perceptions of the West in Nineteenth-Century Bengal (Oxford University Press: 2002), where the quotation appears on page 267. In an accompanying endnote, Raychaudhuri identifies the original source for the quotation as Vivekananda's Prachya o Paschatya (The East and the West), providing a reference to the Bengali edition of Vivekananda's Complete Works, vol. VI, 149-50. This might suggest that a translation can be found in vol. VI of the English version of Complete Works. Instead, the English version appears in Complete Works, vol. V, 442. Raychaudhuri seems to feel that the Bengali is too idiomatic to admit of precise translation. Not so. The Bengali is clear in the original. Witness this literal translation:

Maddened with newly gaining power, not having a proper sense of right and wrong, cruel like a wild animal, dangerous, lustful, drunkard, doesn't have any idea of morality, mannerless, dirty, materialistic, by hook or crook wants to encroach other land and properties, addicted to power by invading other countries and exploiting their wealth through force and treachery, no faith in heaven, who doesn't know the consciousness, just wants to live a total luxurious materialistic life $-[\mathrm{t}]$ hat is how [I]ndians perceive foreigners. This is how [E] ast perceives $[\mathrm{W}] \mathrm{est}$.

I am indebted to Ravi Chopra at Translation Professionals for this translation. Chopra is a native Bengali speaker.

30. "The East and the West" in The Complete Works Of Swami Vivekananda: Mayavati Memorial Edition, vol. V, 7th edn. (Calcutta: Advaita Ashrama, 1959), 441. I am grateful to the editors at Inference for help in tracking down these sources.

31. I cannot imagine an imperial regime for which this description is less appropriate. Slaves to women and insane in their lusts? Working for the British East India Company, British administrators sometimes took native wives or accepted native concubines, but not with any great sense of moral clarity, as Henry Rawlinson confessed; by the time of the Raj, these relationships had come under frank moral censure; and if those dull, disciplined, dutiful British administrators were slaves to their English wives or insane in their marital lusts, these are circumstances not very widely reported. For Rawlinson, see Lesley Adkins, Empires of the Plain: Henry Rawlinson and the Lost Languages of Babylon (New York: Thomas Dunne Books, 2003), 84, a book that miraculously manages to dim one of the most remarkable figures of the nineteenth century.

32. "The East and the West" in The Complete Works Of Swami Vivekananda: Mayavati Memorial Edition, vol. V, 7th edn. (Calcutta: Advaita Ashrama, 1959), 442-43.

33. Quoted in Sister Nivedita, The Complete Works of Sister Nivedita, vol. 1 (Calcutta: Advaita Ashrama, 1982), 165. There are similar remarks throughout Vivekananda's work.

34. Vivekananda's defense of Indian caste would not be a source of celebration in the knowledge ecosystems of London and New York:

Then what was the cause of India's downfall?-the giving up of this idea of caste. As Gitâ says, with the extinction of caste the world will be destroyed. Now does it seem true that with the stoppage of these variations the world will be destroyed? ... Therefore what I have to tell you, my countrymen, is this, that India fell because you prevented and abolished caste. ... Let Jati have its sway; break down every barrier in the way of caste, and we shall rise.

The Complete Works of Swami Vivekananda, vol. 4, 12th edn. (Calcutta: Advaita Ashrama, 1958), 372. Well, well, well. See Ramesh Majumdar, Swami Vivekananda: A Historical Review (Calcutta: Advaita Ashrama, 1999), for references to Vol. 4 of Vivekananda's complete works. S. Debnath, N. Barman, and R. C. Majhi, "Vivekananda's View on Caste," International Journal of Current Research 7, no. 4 (2015): 14,640-42, offers a most forgiving assessment of Vivekananda's views.

35. See, for example, Travis Webster, "Secularization and Cosmopolitan Gurus,” Asian Ethnology 75, no. 2 (2016): 327-57. 
36. For a perceptive and wide-ranging discussion, see Meera Nanda, Prophets Facing Backward: Postmodern Critiques of Science and Hindu Nationalism in India (New Brunswick: Rutgers University Press, 2003).

37. Prime Minister Narendra Modi is piously devoted to Vivekananda's memory. See "PM Modi Unveils Swami Vivekananda Statue on JNU Campus," theprint.in, November 12, 2020. For a somewhat more tart appreciation, see Girish Shahane's remarks: "Role Model: How Vivekananda Laid the Foundation for India's Politics of Sectarianism," Scroll.in, September 13, 2017:

In his brief Chicago address, Vivekananda lamented the fact that "sectarianism, bigotry, and its horrible descendant, fanaticism, have long possessed this beautiful earth." Paradoxically, he laid much of the ideological foundation for the politics of sectarianism and bigotry in modern India. It is peculiarly appropriate that his celebrated speech on tolerance would be the subject of a nationally televised tribute by the man who represents the most dangerous strain of intolerance in India today.

38. Pankaj Mishra, “Modi’s Idea of India," The New York Times, October 24, 2014.

39. Mishra, Bland Fanatics, 10.

40. Berman has summarized some of the points he makes in an essay entitled "The Philosopher of Islamic Terror," The New York Times, March 23, 2003.

41. Sayyid Qutb ash-Shaheed, The America I Have Seen: In the Scale of Human Values, reprinted in Kamal Abdel-Malek, ed., America in an Arab Mirror: Images of America in Arabic Travel Literature: An Anthology (London: Palgrave, 2000), 40.

42. Saint Jerome, Letters and Select Works, Letter 117, translated by William Henry Fremantle, George Lewis, and William Gibson Martley, Nicene and Post-Nicene Fathers, Second Series, vol. 6, eds. Philip Schaff and Henry Wace (Buffalo: Christian Literature Publishing Co., 1893), 350. The Old Boy cannot let it go:

If it is good not to touch a woman, it is bad to touch one: for there is no opposite to goodness but badness. But if it be bad and the evil is pardoned, the reason for the concession is to prevent worse evil. But surely a thing which is only allowed because there may be something worse has only a slight degree of goodness.

Saint Jerome, Letters, Letter 48.

43. Marie Louise Burke, Swami Vivekananda in the West: New Discoveries, vol. 6 (Calcutta: Advaita Ashrama, 1987), 155.

44. Vivekananda's letter to Ramakrishnananda is quoted in Narasingha Sil, Swami Vivekananda's Concept of Woman.

45. Bhagavad Gita, chapter 1, verse 41.

46. Saadat Manto quoted in William Dalrymple, "The Great Divide: The Violent Legacy of Indian Partition," The New Yorker, June 22, 2015.
47. Sarfraz Manzoor, "Saadat Hasan Manto: 'He Anticipated Where Pakistan Would Go', 'The Guardian, June 11, 2016.

48. Throughout what Mishra writes, victims are vouchsafed an indemnity of sorts: they are blameless. In writing about the US Violent Crime Control and Law Enforcement Act, a subject about which he knows nothing whatsoever, Mishra describes Ronald Reagan and Bill Clinton as "two hectic jailers of African Americans," as if black crime rates were an illusion and black incarceration rates the reflection of nothing more than a political whim. (Mishra, Bland Fanatics, 140.) It is an attitude that defeats every honest assessment. It is an attitude, as well, that Swami Vivekananda deplores in discussing the easy Indian attitude toward poverty as a spiritual benefit. Christopher Bayly has remarked on the temptation among contemporary historians simultaneously to assign and deny autonomy to peasants, tribesmen, women, or the working class when it serves various ideological purposes. Christopher Bayly, The Birth of the Modern World (Oxford: Blackwell, 2004), 280. It is a temptation that Mishra indulges, his admiration for Bayly notwithstanding.

49. Mishra, Bland Fanatics, 184.

50. "Take India," Winston Churchill thundered, "if that was what you want! Take it, by all means! But I warn you that if I open the door a crack, there will be the greatest bloodbath in all history; yes, bloodbath in all history." Churchill, quoted in Nisid Hajari, "The Tragedy of India's Partition, 70 Years On," The Japan Times, August 16, 2017. Churchill was, at least, correct in his general appreciation, if somewhat hysterical in his judgment.

51. Alex Von Tunzelmann, "Who Is to Blame for Partition? Above All, Imperial Britain," The New York Times, August $18,2017$.

52. Reinhold Niebuhr, quoted in Mishra, Bland Fanatics, 88.

53. Mishra refers to Larry Siedentop's Inventing the Individual: The Origins of Western Liberalism (Cambridge: Belnap Press, 2014), but the quotation appears in Larry Siedentop, "Remember the Religious Roots of Liberal Thought," The Financial Times, January 23, 2016.

54. Mishra, Bland Fanatics, 91. What would Mishra make of the revelation that Bronisław Malinowski, widely considered an anthropologist committed to grasping the native point of view, regarded the natives with unrelieved contempt and was eager to get as far away from them as possible? It is a rhetorical question. See Clifford Geertz, "From the Natives Point of View': On the Nature of Anthropological Understanding," Bulletin of the American Academy of Arts and Sciences 28, no. 1 (1974): 26-45, doi:10.2307/3822971. This essay reflects Geertz's mature appreciation. On reading Malinowski's diaries for the first time, Geertz had rather a different opinion, describing Malinowski as "a crabbed, self-preoccupied, hypochondriacal narcissist, whose fellow-feeling for the people he lived with was limited in the extreme." A man after my own heart, I must say. Clifford Geertz, "Under the Mosquito Net,” New York Review of Books, September 14, 1967, 12.

55. Mishra, Bland Fanatics, 27. 
56. See my own "A Natural History of Curiosity," Inference: International Review of Science 1, no. 2 (2015):

The observatory at Samarkand was dedicated to a thirty-year program, one longer than anything envisioned, by way of comparison, for the Hubble space telescope. The observatory was grand in its physical aspects. The sextant used to measure the ecliptic had a radius of almost $40 \mathrm{~m}$, roughly comparable to the radius of the reflecting telescope at Mt. Palomar. The building was constructed of marble, and it housed exquisite brass and copper instruments. After Ulugh Beg's death, the observatory was sacked by local rulers, unable to resist its wealth, and by local clerics, unwilling to abide its learning.

57. See reviews by F. Jamil Ragep, Renaissance Quarterly 61, no. 1 (2008): 245-47, doi:10.1353/ren.2008.0125; and John Walbridge, Early Science and Medicine 12, no. 4 (2007): 440-42, doi:10.1163/157338207X231440.

58. I have discussed the end of Islamic science in "A Natural History of Curiosity." See also Samer Akkach, Destroying the Observatory and Observing the Destruction: the Istanbul Observatory (Doha: Arab Center for Research and Policy Studies, 2017).

59. Ferguson quite specifically calls attention to the fall of the observatory, as well. Niall Ferguson, Civilization: The West and the Rest (London: The Penguin Group, 2011), 69, a point that Mishra, no doubt, overlooked. Who am I to complain? I overlooked it too. I am grateful to Ferguson for calling my attention to his remark.

60. Mishra, Bland Fanatics, 91.

61. In considering, say, Thomas Wilson's "The Ritual Formation of Confucian Orthodoxy and the Descendants of the Sage," Journal of Asian Studies 55, no. 3 (1996): 559-84, doi:10.2307/2646446, Mishra would not dream of advising Wilson to attend to mankind's other conversations with itself. His good advice is une rue à sens unique.

62. Alan Ryan, "Why Herodotus?" in On Politics: A History of Political Thought from Herodotus to the Present (New York: Liveright Publishing, 2012), 6.

63. David Nivison, "Mencius and Motivation," Thematic Issue S, supplement to Journal of the American Academy of Religion 47, no. 3 (1980): 417-32, has discussed the very interesting connections between Mencius and Aristotle.

64. I have written about al-Ghazali in The Secrets of the Vaulted Sky. David Berlinski, The Secrets of the Vaulted Sky: Astrology and the Art of Prediction (New York: Harcourt Books, 2003), 115.

65. See Patrick Olivelle, trans., King, Governance, and Law in Ancient India, Kautilya's Arthaśāstra (Oxford: Oxford University Press, 2013). From the publisher's description:

It codifies a body of knowledge handed down in expert traditions. It is specifically interested in two things: first, how a king can expand his territory, keep enemies at bay, enhance his external power, and amass riches; second, how a king can best organize his state bureaucracy to consolidate his internal power, to suppress internal enemies, to expand the economy, to enhance his treasury through taxes, duties, and entrepreneurial activities, to keep law and order, and to settle disputes among his subjects.

66. Kauțilya's Arthaśāstra, trans. R. Shamasastry, 4th edn. (Mysore, India: Sri Raghuveer Printing Press, 1951).

67. Shamasastry, Kautilya's Arthaśāstra, 20. For readers worried about poison, there is this: if your food is

devoid of smell, touch and taste natural to them; when utensils reflect light either more or less than usual, and are covered with a layer of foam at their edges; when any liquid preparation possesses streaks on its surface; when milk bears a bluish streak in the centre of its surface; when liquor and water possess reddish streaks; when curd is marked with black and dark streaks, and honey with white streaks; when watery things appear parched as if overcooked and look blue and swollen; when dry things have shrinked and changed in their colour; when hard things appear soft, and soft things hard; when minute animalculæ die in the vicinity of the dishes; when carpets and curtains possess blackish circular spots, with their threads and hair fallen off; when metallic vessels set with gems appear tarnished as though by roasting, and have lost their polish, colour, shine, and softness of touch, presence of poison shall be inferred.

Shamasastry, Kautilya's Arthaśāstra, 42. Clem Tisdell has argued that the Arthaśāstra "shows a knowledge of basic economics that had no parallels in Western economic thought until the publication of Adam Smith's Wealth of Nations in 1776." Clement Tisdell, "A Western Perspective on Kautilya's 'Arthasastra': Does It Provide a Basis for Economic Science?" Economic Theory, Applications and Issues Working Papers 90523, University of Queensland, School of Economics, doi:10.22004/ag.econ.90523. Tisdell's question is easily answered: no.

68. Kautilya's Arthaśāstra, 7 .

69. Vincent Smith, Asoka: The Buddhist Emperor of India (Oxford: Clarendon Press, 1920), 185.

70. This is Ashoka's 2nd Pillar Edict. For a translation, see Romila Thapar, Aśoka and the Decline of the Mauryas (Delhi: Oxford University Press, 2018), 262.

71. One of Goethe's jingly little poems. Johann Wolfgang von Goethe, "Erinnerung," in Gedichte: Ausgabe letzter Hand 1827 (Stuttgart \& Tübingen: Cotta, 1827), 56.

72. Mishra, Bland Fanatics, 9.

73. Mishra, Bland Fanatics, 32.

74. Mishra's confident assumption that Muslim birth rates in France are destined to decline, insofar as it is based on anything at all, is based on a report by the Pew Foundation, 
which, in turn, involves a projection from current trends. See "Europe's Growing Muslim Population," Pew Research Center, November 29, 2017. The title itself might have persuaded Mishra to reconsider his very confident asseverations about declining Muslim birth rates.

75. Christopher Caldwell, quoted in Pankaj Mishra, "A Culture of Fear," The Guardian, August 15, 2009.

76. I discuss the outbreak of the First World War in "The Best of Times," Inference: International Review of Science 1, no. 4 (2015).

77. Mishra, Bland Fanatics, 9.

78. The following attentats are of recent memory: in 2012 in Toulouse and Montauban, three French paratroopers, a rabbi, and three schoolchildren killed; in 2015 in Paris, twelve dead in the Charlie Hebdo attack; in 2015, Saint-Quentin-Fallavier, one dead by decapitation; again in 2015, at the Bataclan and other coordinated locations around Paris, 130 dead; in 2016 in Magnanville, two dead; again in 2016, in Nice, eightysix dead; and again in 2016, at the Normandy church attack, one dead; 2017 in Paris, one suicide; 2017 in Marseille, two dead; 2018 in Carcassonne and Trèbes, four dead; 2018 in Strasbourg, five dead; 2019 at a Paris police headquarters, four dead; 2020 in Villejuif, one dead; 2020, Romans-surIsère, two dead; 2020 in Conflans-Sainte-Honorine, the beheading of Samuel Paty; in 2020, Nice, three dead. Writing in 2009, Mishra could not have foreseen these events. But he might have refrained from republishing this very silly essay.

79. Now named the Rassemblement National. It is astonishing that Mishra's editors could not get even this obvious detail right. Mishra does take a whack at Le Pen senior, Jean-Marie Le Pen, a hard-bitten, endlessly entertaining former French paratrooper, whom Mishra incomprehensibly refers to as a "neo-anthropologist"; Bland Fanatics, 132. Mishra has Le Pen saying: "I love Maghrebins ... but their place is in the Maghreb." There is no source for the quotation and I have been unable to find it in English or in French. Le Pen seems to have made similar remarks about Turkey: "In the same way, we do not hate the Turks, we love them, but in their country." I can find no French source for this quotation either. The allusion is to Joan of Arc's famous response to her inquisitors:

A Rouen, on tenta de faire "déraper" Jeanne, comme on dirait aujourd'hui. L'un des juges, ecclésiastiques, rappelons le, lui dit : "Jeanne, Dieu nous fait devoir d'aimer notre prochain, aimez-vous les anglais ?” Répondre négativement la faisait considérer comme hérétique.

Miracle de finesse, d'intelligence et d'humour français, Jeanne répondit : "J'aime les anglais... chez eux!"

This is a quotation from Le Pen: "Déclaration de M. Jean-Marie Le Pen, président du Front national, sur les principaux axes du programme politique du FN après les élections régionales et à la veille des élections européennes, Paris le ler mai 2004," Vie-publique.fr.
80. Mishra, Bland Fanatics, 132.

81. Quoted in my own The Secrets of the Vaulted Sky, 123.

82. Consider:

The Germans made fun of the Austrians ... Those born in East Prussia were considered ignorant hawbucks. The Bavarians laughed at the Berliners, saying that Berlin was a Jewish city ... The Prussians, the Bavarians and the Berliners all despised the Alsatians, calling them foreign swine.

This is not de Vitry. It is Vasily Grossman's novelized description of the Wehrmacht at the very height of Operation Blau in the summer of 1942. Vasily Grossman, Stalingrad (London: Vintage, 2019), 793.

83. Mishra, Bland Fanatics, 41-42. If Mishra is persuaded that the secular intellectual priesthood cannot survive without a theological opposition between the Enlightenment and Islam, he has, I assure him, grossly underestimated the secular intellectual priesthood. Like the cockroach, it can survive anything.

84. Section III of the 1913 Imperial German Reichs-und Staatsangehörigkeitsgesetz, which deals with naturalization, does not say a word about it.

85. Jean-Marie Le Pen, April 2, 1987, quoted in "Discours aux jeunes beurs arrogants," Le Monde, April 4, 1987.

86. See Jeremy Harding, "Charlie's War," in The London Review of Books 43, no. 3 (2021), for an informed, sympathetic, but slightly fruity discussion.

87. The French in 2004 did ban headscarves in the public schools. The title of the relevant law is clear enough: Le loi $n^{\circ}$ 2004-228 du 15 mars 2004 encadrant, en application du principe de laïcité, le port de signes ou de tenues manifestant une appartenance religieuse dans les écoles, collèges et lycées publics. The law does not once mention the Muslim community. And it does not, as Mishra imagines, demand of any group that they "renounce all signs of their religion."

88. William Rogers Brubaker, "The French Revolution and the Invention of Citizenship," French Politics and Society 7, no. 3 (1989): 30-49. "A nation state is a nation's state," Brubaker writes,

the state of and for [emphasis original] a particular, bounded, sovereign nation to which foreigners, by definition, do not belong. Legally homogeneous internally, it is by virtue of this very fact more sharply bounded externally than an internally heterogeneous state such as pre-revolutionary France.

Brubacker, "French Revolution," 43. This seems to me to involve an extraordinary exaggeration; and, in any case, it is hardly clear that contemporary France is more "legally homogeneous" than pre-revolutionary France. Carl Schmitt is, no doubt, eager to say something the moment he returns from the Bauernkeller. 
89. Mishra, Bland Fanatics, 35 .

90. In a remark of some irony, a young German architectural student once observed to me that with the disappearance of the Jews, "Germany had lost its salt" (Deutschland hatte sein Salz verloren). The Germans have generally adapted to a salt-free diet with remarkable equanimity. The raw statistics in Central and Eastern Europe bear this out. They are depressing. See Leszek Kosiński, "Changes in the Ethnic Structure in East-Central Europe, 1930-1960," Geographical Review 59, no. 3 (1969): 388-402, doi:10.2307/213483. The abstract for the essay notes that Kosiński studied the "ethnic composition of population in seven countries-Poland, Czechoslovakia, Hungary, Rumania, Bulgaria, Yugoslavia, and Albania." "During that period," the abstract points out, "the size and proportion of minorities in East-Central Europe declined from 24 million (26 percent) before World War II to 7.1 million (7.2 percent) at present."

91. They are surely correct about Poland: See Eukasz Grochowalski et al., "Y-Chromosome Genetic Analysis of Modern Polish Population," Frontiers in Genetics 11 (2020), doi:10.3389/fgene.2020.567309. The authors confirm the obvious prediction: "the Polish population is characterized by a high degree of homogeneity, with only slight genetic differences being observed at the regional level." And the obvious cause: "the greatest influence for the shaping of [the] modern demographic situation [was] World War II."

92. See Ulrike von Hirschhausen, "From Imperial Inclusion to National Exclusion: Citizenship in the Habsburg Monarchy and in Austria 1867-1923," European Review of History 16, no. 4 (2009): 551-73, doi:10.1080/13507480903063860. "An evaluation of applications for Austrian naturalisation," Hirschhausen writes, "illustrates the remarkable capacity of Austrian citizenship law to integrate and to uphold a concept of nationality independent from ethnicity, religious denomination, class or gender." What changed after World War I was far more a matter of race than ethnic identity; but race is no more a reputable concept than ethnic identity itself.

93. Elie Halévy, The World Crisis of 1914-1918 (Oxford: Clarendon Press, 1930), 37. See, as well, Marco Bresciani, "From 'East to West,' the 'World Crisis' of 1905-1920: A Re-reading of Elie Halévy," First World War Studies 9, no. 3 (2018): 275-95, doi:10.1080/19475020.2019.1651212.

94. Pieter Judson, The Habsburg Empire (Cambridge, MA: The Belknap Press, 2016), 451, but see the whole of the epilogue. Judson's frankly revisionist work represents a growing but little noticed split between historians of the First World War and historians of the Habsburg Empire. "General treatments of the First World War are either surprisingly uninformed about the monarchy or their information is hopelessly outdated," John Deak remarks in "The Great War and the Forgotten Realm: The Habsburg Monarchy and the First World War," Journal of Modern History 86, no. 2 (2014): 337, doi:10.1086/675880.

95. The smaller states of central Europe had occasion for historical nostalgia when they discovered what should all along have been obvious: that without the protection of the Empire they had worked so long to destroy, they were naked in the world of predatory states, the Germans seeking to subdue them and the French unwilling to protect them.

96. Michael Banton, "Max Weber on 'Ethnic Communities': A Critique," Nations and Nationalism 13, no. 1 (2007): 26, doi:10.1111/j.1469-8129.2007.00271.x.

97. Mishra, Bland Fanatics, 10.

98. See Emmanuel Dalle Mulle, "The Pursuit of Polish Homogeneity Following World War II," The Myth of Homogeneity: Minority Protection and Assimilation in Western Europe, 1919-1939 (blog), February 20, 2020.

Mulle makes the obvious point: that post-war ethnic cleansing was incoherent. See, in addition, Alessandro Ambrosino, "Minorities in Contemporary and Historical Perspective: 1919-2020 and Beyond," The Myth of Homogeneity: Minority Protection and Assimilation in Western Europe, 1919-1939, December 23, 2020.

John Kulczycki, quoted within the same article, remarks that if "[r]ecovering 'Polish souls' became a national priority," it was one

for which officers tasked with inquiring into the ethnic nature of the inhabitants of these regions received few guidelines. After about two years of mass expulsion, the Polish Ministry of the Recovered Lands had to recognize "the impossibility of creating an objective criterion that would differentiate a German from an autochthon."

99. Johnson, "Review of Thomas Blackwell's Memoirs," 533. Dr. Johnson has a sympathizer in Rebecca West, who in Black Lamb and Grey Falcon (London: Macmillan, 1941), argued counterfactually for the depth and dignity of a world in which Roman power had not suppressed a variety of local cultures. If her argument is unanswerable, it is only because its conclusion is undecidable. Simone Weil has made a similar argument.

100. Tacitus, Agricola, ch. 30.

101. Moses Hadas, A History Of Rome from Its Origins to 529 A. D. As Told by the Roman Historians (New York: Doubleday, 1956), 142-43.

102. See Harshan Kumarasingham, "Eastminster-Decolonisation and State-Building in British Asia," in Constitution-Making in Asia:Decolonisation and State-Building in the Aftermath of the British Empire, ed. Harshan Kumarasingham (London: Routledge, 2016), 1-35.

103. V. S. Naipaul, $A$ Writer's People (London: Picador, 2007), 177. 104. Nirad Chaudhuri, Autobiography of an Unknown Indian (New York: New York Review of Books, 2001), 1.

105. V. S. Naipaul, An Area of Darkness (London: Andre Deutsch, 1964), 213.

Mishra writes:

Englishness was always a form of theatre, first scripted and staged in England's colonies. Discovering its 
traces in Kipling and India, V. S. Naipaul remarked on how "at the height of their power, the British gave the impression of a people at play, a people playing at being English, playing at being English of a certain class." Today, in a post-imperial Britain run by half-witted public schoolboys, the English "character" seems even more, as Naipaul wrote, "a creation of fantasy."

Mishra, Bland Fanatics, 201. It is impossible to take this seriously. In An Area of Darkness, Naipaul is discussing Philip Woodruff's The Men Who Ruled India: The Founders of Modern India (New York: St. Martin's Press, 1954). In his review of Woodruff, American Historical Review 60, no. 1 (1954): 109-10, doi:10.1086/ahr/60.1.109, Holden Furber recounts the achievement of one such founder:

Robert Bird, who struggled for seven years, 1833-1840, to define the property rights of $23,000,000$ people in the then Northwest Provinces (now Uttar Pradesh) recording "the separate possession, rights, privileges, and liabilities of the members of those communities who hold their land in severalty, and the several interests of those who hold their land in common."

Furber, "Review of The Men Who Ruled India," 109. This administrative achievement does not quite sound as if it were the work of a man at play. The British may well have been playing a role in India, but it was the role that competent and determined administers have always played. The founders of modern India do not seem all that different from the founders of modern Britain, the Duke of Normandy's tough, unsentimental, determined, and often ruthless administrators. Britain was, of course, a part of the Angevin Empire.

DOI: $10.37282 / 991819.21 .2$ 